\title{
РАДИАЦИОННО-СТИМУЛИРОВАННАЯ ТРАНСФОРМАЦИЯ СПЕКТРОВ ОТРАЖЕНИЯ ПЛЕНОК ДИАЗОХИНОН-НОВОЛАЧНОГО ФОТОРЕЗИСТА ПРИ ИМПЛАНТАЦИИ ИОНОВ СУРЫМЫ
}

\author{
(C) 2020 г. А. А. Харченко ${ }^{a, b}, *$, Д. И. Бринкевич ${ }^{a, * *}$, В. С. Просолович ${ }^{a}$, \\ С. Д. Бринкевич ${ }^{a}$, В. Б. Оджаев ${ }^{a}$, Ю. Н. Янковский ${ }^{a}$ \\ ${ }^{a}$ Белорусский государственный университет, Минск, 220030 Беларусь \\ ${ }^{b}$ Научно-исследовательское учреждение “Институт ядерных проблем” Белорусского государственного \\ университета, Минск, 220030 Беларусь \\ *e-mail:XaaTM@mail.ru \\ **e-mail: brinkevich@bsu.by \\ Поступила в редакцию 12.09.2019 г. \\ После доработки 22.11.2019 г. \\ Принята к публикации 25.11.2019 г.
}

\begin{abstract}
Измерением спектров отражения исследованы имплантированные ионами сурьмы пленки фоторезиста ФП9120 толщиной 1.8 мкм, нанесенные методом центрифугирования на поверхность пластин кремния $p$-типа ( $\rho=10$ Ом · см) с ориентацией (111). Показано, что имплантация приводит к уменьшению показателя преломления фоторезиста, обусловленному радиационным сшиванием молекул новолачной смолы, а также снижением молекулярной рефракции и плотности фоторезиста. В области непрозрачности фоторезистивной пленки при увеличении дозы имплантации наблюдается рост коэффициента отражения.
\end{abstract}

Ключевые слова: литография, излучение, подложка, фоторезист, имплантация, сурьма, показатель преломления, отражение.

DOI: $10.31857 / \mathrm{S} 1028096020060084$

\section{ВВЕДЕНИЕ}

Исследование радиационно-индуцированных процессов в полимерах представляет практический интерес, поскольку полимерные композиции активно используются в качестве резистов в процессах электронной, фото- и рентгеновской литографии при производстве интегральных микросхем [1-8]. Следует также отметить, что в настоящее время основным методом легирования в микро- и наноэлектронике является ионная имплантация [9]. Повышение степени интеграции предъявляет высокие требования к блоку операций, обеспечивающих маскирование ионного пучка. В качестве масок в современных литографических процессах важную роль играют диазохинон-новолачные (ДХН) резисты [1]. Взаимодействие ДХН-резистов с дальним ультрафиолетом, рентгеновским и видимым излучением исследовано достаточно подробно [1]. Однако влияние ионной имплантации на свойства указанных резистов изучено недостаточно, хотя протекающие при ионной имплантации радиационно-индуцированные процессы могут оказывать существенное влияние на качество создаваемых приборов.
Целью работы являлось исследование радиационно-стимулированной трансформации спектров отражения позитивных ДХН-резистов при имплантации ионов сурьмы.

\section{МАТЕРИАЛЫ И МЕТОДЫ}

В настоящей работе исследовались радиационно-индуцированные процессы при имплантации ионами $\mathrm{Sb}^{+}$-пленок промышленного позитивного фоторезиста ФП9120, представляющего собой композит из светочувствительного о-нафтохинондиазида и фенолформальдегидной смолы. Пленка фоторезиста толщиной 1.8 мкм наносилась промышленным способом на поверхность пластин кремния $p$-типа $(\rho=10$ Ом $\cdot$ см) с ориентацией (111) методом центрифугирования при скорости вращения 1800 об/мин. Перед формированием пленки фоторезиста кремниевые подложки подвергали стандартному циклу очистке поверхности в органических и неорганических растворителях. Время вращения центрифуги - 40 с. После нанесения фоторезиста на рабочую сторону кремневой подложки проводилась сушка в течение 50-55 мин при температуре $88^{\circ} \mathrm{C}$. Толщина 